\title{
MACEDONIAN CONSTITUTIONAL COURT AND THE PRESPA AGREEMENT: UNBEARABLE EASE OF INACTIVITY
}

\author{
Tanja KARAKAMISHEVA-JOVANOVSKA, ${ }_{1}^{1}$
}

Faculty of Law "lustinianus Primus", Skopje and former member of the Venice Commission

\author{
Dejan SAVESKI,
}

$\mathrm{PhD}$ in Law, Faculty of Law "lustinianus Primus", Skopje

\begin{abstract}
The Constitutional Court is entitled to play the role of a protector of the Constitution as well as to be an ultimate guardian of the rule of law. Whether and how successful the Macedonian Constitutional Court is in its role is not a question of any subjective assessment. On the contrary, it is an issue that calls for an overall objective and critical analysis of its actions. Particularly in 2017 and 2018, many unconstitutional political activities took place, on which the Constitutional Court decided to remain mute. It did not rule on the constitutionality of the amendments, remained silent on the referendum and the Prespa Agreement (PA). Practically, on the key issues of importance for the state - its name, history and identity - the Court did not take any position, which has devastating effects on the institution and rule of law in general. Bearing in mind that the Constitution does not contain prohibitions or clauses that would prevent altering of certain constitutional provisions (as numerous constitutions have), with the 2018 constitutional amendments (published in the "Official Gazette" on 12 January 2019), the Macedonian Parliament amended the constitutional provisions that go into the essence of the Macedonian statehood and nationhood - i.e., historical facts were changed in the Preamble as well as the name of the state. In the light of the fact that the constitutional amendments were adopted under pressure to implement the unconstitutional PA, concluded by an incompetent body (the Minister of Foreign Affairs), contrary to the existing laws, the Constitution and the international law, then the question of the role of the Constitutional Court in these events gains extra weight. The paper deals with the failure of the Constitutional Court to act when the most essential (national) issues were at stake, until the day of writing this paper.
\end{abstract}

Keywords: Prespa Agreement², Constitutional Court, competencies, Constitution, politics, constitutionality

\footnotetext{
1 Contact address: tanja.karakamiseva@gmail.com.

2 The original name of Prespa Agreement is "Final Agreement for the Settlement of the Differences as Described in the United Nation Security Council Resolutions 817 (1993) and 845 (1993), the Termination of the Interim Accord of 1995, and the Establishment of a Strategic Partnership between the Parties".
} 


\section{Introduction: The Name of the State Belongs to the People}

The name of the state is the core of not only individual but also collective constitutional and national identity. The ability of a nation and the citizens to choose the name of their political community is one of the key aspects of the political and cultural identity of that community. As Stefov (2018) puts it, the name of the state belongs to the people. In other words, this right is an emanation of the Macedonian people's fundamental right to internal self-determination. It belongs only to the Macedonian people and the other national minorities. In consequence, any sitting government is unable to waive the Macedonian people's right to self-determination protected by international law (Janev 1999, p. 159). ${ }^{3}$

According to the Constitution, Macedonia is a state whose sovereignty derives from the citizens and belongs to the citizens. Furthermore, it stipulates that respect for the norms of general international law in one of the fundamental values of the constitutional order. Also, pursuant to Article 8 of the Constitution, the free expression of national identity is one of the fundamental values of the Macedonian constitutional order.

The June 2018 Agreement's contravention of the right of the Macedonian people to self-determination (Brown 2003) may go beyond the PA's provisions, bearing in mind that the Agreement as such was concluded in accordance with Greece's long-term effort to deny identity and history of Macedonians (and to do so also concerning Macedonians living within the borders of their sovereign state). The incumbent Macedonian Government has colluded with Greece and the certain Western States over such policies (Mircev, 2001).

The right to internal self-determination of an entire population of a State is enshrined in the Human Rights Covenants 4 , the UN Friendly Relations Declaration, and other international documents. No State may deny the population to choose the name of its existing State in the exercise of its right to self-determination.

\section{The Aspects of the Constitutional Procedural Omission of the Prespa Agreement}

According to Article 119 of the Constitution, the President of the Republic is a public authority who can create any implications in the legal system by concluding international agreements. International agreements are concluded in the name of the Republic by the President (Article 119 para 1 of the Constitution). International agreements may also be concluded by the Government when it is determined by law (Article 119 para 2 of the Constitution). According to this article, the President is primus, while the Government is secundus. The President of the Republic has a privileged status concerning the authority for concluding international treaties in the name of the state originates from the constitutional provision.

\footnotetext{
3 Janev is also right to note that the forcing of Macedonia to accept the temporary reference FYRoM for the sake of its UN membership, represents an additional condition that is not foreseen in Article 4, Paragraph 1 of the UN Charter, which foresees general but no additional conditions for membership in the UN.

4 The Republic of Macedonia is a party to both International Covenant on Civil and Political Rights, 1966 and International Covenant on Social, Economic and Cultural Rights, 1966.
} 
On the other hand, according to Article 3, item 2 of the Law for Conclusion, Ratification, and Execution of International Agreements, the Government have some authorization competencies for concluding the international agreements. According to the Constitution, it means that in addition to the President, the Covernment could also be a party in the conclusion of certain international agreements in the sixteen enumerated fields, such as: 1) economy, 2) finance, 3) science, 4) culture, 5) education and sports, 6) transport and communications, 7) urbanism, 8) architecture and environment, 9) agriculture, forestry, and water management, 10) health 11) energy, 12) justice, 13) labor and social policy, 14) human rights, 15) diplomatic-consular relations, and 16) defense and security.

Nowhere in the Constitution or the law is there an explicit provision that gives the Government the right to conclude international agreements of a political nature, and especially agreements that change the state name, national identity, and history of the country. It is a fact that such an international agreement cannot be concluded under the international law. This provides a legal basis for its unilateral termination.

The same constitutional article stipulates that for association with (or dissociation from) any union or alliance with other states as well as in concluded with other international agreement which according to international law are a matter of habit, they are to be concluded by the head of state (i.e., by President of the Republic of Macedonia).

The PA was signed by the two Ministers of Foreign Affairs (more about the Agreement in its content and geopolitical effects see: Vankovska 2020, Heraclides 2020). The legitimate question reads: under which constitutional or statute grounds the Macedonian minister Nikola Dimitrov has signed an international agreement that affects the Macedonian identity components, particularly the right to self-determination? (Saveski, 2020).

Hence, the legal answer to this question derives from the aforementioned Law for the Conclusion, Ratification, and Execution of International Agreements, but also the Law on Foreign Affairs, both that precisely define the status of the Foreign Affairs Minister as a government official regarding state's international relations. The laws that regulate authorization for concluding international agreements as well as the entitlements of the foreign affairs minister in the process that precedes the act of the State's committing to any treaty provide the following:

First, the President of the Republic has exclusive jurisdiction in the negotiating process, including the act of signing international agreements, which have not included the numerus clausus principle regulated in Article 3, para 2 in the Law for the Conclusion, Ratification, and Execution of the International Agreements. Accordingly, this particular deed of the Minister of Foreign Affairs means that he undertook an action out of his jurisdiction. In other words, it ultra vires act that violates the fundamental legal norms in the process of signing the international agreement.

Second, the procedure for negotiating international agreements must be initiated by the President of the State. The decision for the inauguration of the negotiation process is made by the President who takes the initiative whenever he thinks that the country should be a party to an international agreement. Also, there is another situation in which the President is enforced to 
make this decision if the majority of voters in a national referendum adopted the decision under the condition that more than half of the total number of voters cast their votes.

Third, the President is to start a negotiation process on the conclusion of an international agreement if the Assembly adopts a decision, or if the proposal to start the negotiations comes from the Government. When a proposal originates from these instances, the final decision to begin with the negotiation process is made by the President. But in the case in focus here, the act of negotiation was not taken under the statute entitlement, as the President was precluded from the negotiation process in the Prespa Agreement process (Saveski, ibid).

The Government did not have any authority to negotiate over the PA, because the subject regulated by the treaty - i.e. the name of the country "Republic of Macedonia" - do not comply with the provisions of Article 3 para 2 of the Constitution, which enumerate the fields in which the Government could be active in this field. One should keep in mind that the state's name stems from the right of self-determination of the nations, which according to the international law have a status of ius cogens norm. With respect to the Macedonian constitutional norms, ius cogens norms in the domestic law hold a status of constitutional norms albeit their origin is in the international law. Such international norms could be changed only by another legal norm with identical legal force and adopted in an adequate procedure. In other words, they may be altered only through another multilateral international agreement, but not through a bilateral agreement or constitutional amendments to any national constitution.

\section{The Constitutional Court's Indifference in Context of the Prespa Agreement}

The Macedonian Constitutional Court's treatment of the relationship between international and national law has been highly controversial (Karakamisheva-Jovanovska 2018). On the other hand, the Constitution does not stipulate any competence of the Constitutional Court to review the constitutionality of international treaties. It means that the Court does not have any competence to review the conformity of laws with the ratified international treaties.

However, bearing in mind that according to the Constitution, the ratified treaties become an integral part of the internal legal order with a rank under the constitutional norms, one could conclude based on past practice and judges' opinions, the Court still have two options: either to keep with the constitutional provision listing its competences where international treaties are not mentioned as an object of review (Article 110), or to build its competence on the theory ground which argues that once the ratified international treaty becomes a part of the domestic legal order, accordingly it has to be in accordance with the Constitution, and therefore reviewable by the Court (Spirovski 2009).

It is worth mentioning also that the primary constitutional rule is that the international agreements are to compliance with the Constitution, which does not imply that the Constitution should be adapted to the international agreements, as it was the case with the PA, then it is quite clear that the Court decided to deliberately remain a silent witness to the violation of the international law and the national Constitution due to political and not legal considerations. Article 53 of the Vienna Convention on the Law of Treaties stipulates that international agreements 
must not violate ius cogens norms and if this happens the agreements become legally invalid (i.e. such treaties could be on object of diplomatic termination in accordance with Articles 46 and 53 of the Convention) (also see: Dialogos Media, 2019, Nikodinovska Krstevska, 2019).

The existing case-law ${ }^{5}$ implies that the Court takes an indifferent position concerning the international law in the context of its status and rank in the hierarchical structure of legal acts. The Court obviously treats it as if it is outside and beyond the constitutional order. Thus, the solutions for possible collusion between domestic and international law are left for the ordinary judges to determine when deciding in concrete cases brought before them (Spirovski, ibid.).

As already mentioned, for the first time in its practice, it was in 2002 that the Constitutional court declared itself authorized to assess the constitutionality of ratified international treaty. With that decision, the Constitutional court repealed the law for ratification of the bilateral agreement on construction and management of the oil pipeline signed between Macedonia and Greece, (Decision U. no. 140/2001-1). According to this decision, and with respect to Article 108 of the Constitution (principles of constitutionality and legality) and Article 110 (court's competence in general), it appears that the ratified international agreement can be subject to review of its constitutionality both on its formal (procedural) and material (substantial) ground in an appropriate procedure. In the further elaboration of its standpoint, the Court confirmed that through the act of ratification, any international agreement becomes a part of the internal legal system; therefore, it gets such a hierarchy status that positions it above the laws yet below the Constitution. In the context of this conventionally accepted legal standard of the monistic doctrine, the ratified international agreements have to be in accordance with the constitutional provisions. In addition to the basic constitutional provisions (i.e. Articles 108 and 110), the Constitutional court also called upon the relevance of the fundamental value, Rule of law (as defined in Article 8, para 1, item c).

Unfortunately, the Constitutional court has not summoned enough courage to establish an independent authorization for reviewing all the ratified international treaties. On the contrary, the Court used the prescribed competence and the posed constitutional question for an overview of the international treaty through a constitutional perspective. In its decision, Court pointed

\footnotetext{
5 In 1994 the Constitutional court, for the first time, announced its position concerning the international agreements' constitutional control. Namely, the Court decided to not open the procedure for reviewing the constitutionality of the Law for ratification of the agreement between the Government of the Republic of Macedonia, and the International Bank for Reconstruction and Development, and the Law for ratification of the international agreement between the Government of the Republic of Macedonia and the International association for development. In the decision for non-initiating the procedure of constitutional review, the court did not declare itself an incompetent authority for Constitutional observation of the international agreements. Also, in that case, the Constitutional court ruled that individual rights stipulated in the Constitution were not violated. (Decision U. no. 46/1994-0-0 http://ustavensud.mk/?p=6253). In 1996, the Constitutional court decided not to initiate the procedure for constitutional control of the international law, but this time the issue in focus was the Law for ratification of the 1995 Interim Accord signed between Macedonia and Greece. (Decision U. no. 341/1995-0-0 http://ustavensud.mk/?p=6599). In 1999, the Constitutional court refused to review the legality of Art. 14, Chapter IV, from the Protocol 2 of the Law for ratification of the 1997 Cooperation Agreement, signed between the Republic of Macedonia and the European Community. In 2001, with reference to Art. 28 par. 1 of its Rule of Procedure, the court, for the first time, proclaimed itself an unauthorized public authority for reviewing the constitutionality of international treaties and rejected the initiative. In this case, the question raised was the constitutionality of a couple of laws for ratification of international treaties connected with NATO.
} 
out the constitutional requirement for obligatory adjustment of the inferior legal norms with the constitutional ones. In other words, in this case, the Constitutional court did not carry out a constitutional review of the Macedonian-Greece bilateral agreement directly and in its essence but reviewed it through the prism of the law for introducing the ratified international treaty into the domestic legal order.

Based on its practice so far, it is correct to conclude that despite the intention of the constitutional creators' not to authorize constitutional review of the international agreements, the Constitutional court may construe for itself a new type of competence and, consequently, to permanently update the allegedly irremovable procedures. In other words, the omission of the constitutional-makers to stipulate the interpretation of the constitutional law by the Court could be used as a ground for promotion of a new model of intervention in the legal system concerning the international agreements. But, the interpretation of the constitutional law in a sense of the Macedonian constitutional law, does not involve the conventionally established method for understanding the constitutional provisions through announcing the individual acts (decisions) (Karakamisheva-Jovanovska 2018). This model of analysis of constitutional law is usually used by the Constitutional Court as a regular tool for understanding the legal system within the framework of the obligations that public authorities have for the application of constitutional provisions. Moreover, if an international agreement contains provisions that violate the Constitution, it is considered not only a violation of the Constitution but also of international law. The effect of the decision of the Constitutional Court should be in the direction that the international agreement is part of the domestic legal order and that it must be in accordance with the Constitution even though it does not lose its legal force in international law.

This case inevitably opens a discussion on a possible reform directed to the introduction of a priori review of the constitutionality of international treaties, which would probably be the most appropriate technique to protect both the constitution and the credibility of the state in international relations.

However, the majority of the present Court's judges has drawn back to the previous stance: they accept the reasoning inter alia that the control of constitutionality of the international agreements is carried out by the Parliament during the ratification process, after which they become part of the domestic legal order as well as self-executing. Interestingly, this alleged function of the Parliament to exercise constitutional review of the international treaties is equally non-existent in the Constitution as it is the competence of the Court to review the constitutionality of the international agreements.

The court does not accept to consider the ratification of an international agreement as a criterion for assessing the legality, because the ratification of the agreements is done by law. Hence, it is impossible to assess the legality of a law, which requires an assessment of the constitutionality of the law. 


\section{Seceururity}

\section{Other Constitutional Dilemmas over the Prespa Agreement}

The Macedonian Constitutional Court, unlike the other European constitutional courts, has no authority to decide on election and referendum issues. The competent courts to review the complaints or appeals in the matters concerning the certification of electoral results are in most countries constitutional courts: such cases include Armenia, Austria, Azerbaijan, Bulgaria, Cyprus, the Czech Republic (as a second instance; in the first instance, it is the Supreme Administrative Court), Estonia, Germany, Liechtenstein, Lithuania, Malta (on some issues also ordinary courts), Portugal and Slovakia. ${ }^{6}$

Thus, it missed the opportunity to decide on the protection of the constitutional and national values in the case of the controversial referendum on the PA, held on 30 September 2018. Despite the initiative for assessing the constitutionality of the parliamentary decision to call a consultative referendum on the PA, by a majority vote the Court decided not to initiate proceedings for the impugned Decision on announcing a referendum no.08-4666/1 adopted by the Assembly of the Republic of Macedonia on 30 July 2018 ("Official Gazette of the Republic of Macedonia" no.140/2018). The Court's view outlined in its resolution is that under the Constitution, the role and function of the citizen is to "produce" concrete political institutions and public authorities that will respect the fundamental constitutional values as their home and decide directly (through referendum and other forms of direct expression) without going into the unconstitutional and illegal content of the decision itself.

According to the minority opinion, the Court's decision to announce a referendum was contrary to Articles 1, 2, 8 paragraph 1 lines 1, 3, 5 and 11, Article 50 paragraph 3, Article 51, Article 54 paragraph 1, Article 73, Article 74 paragraph 2, Article 118, Article 119 paragraph 1, Article 120 and Article 121 of the Constitution of the Republic of Macedonia and in contradiction with Article 2, Article 9, Article 15 paragraphs 3 and 4, Article 21, Article 24, Article 27 and Article 29 of the Law on Referendum and Other Forms of Direct Expression of the Citizens. The Decision on announcing a referendum notes that the citizens will give their opinion on the question "Are you for membership in the EU and NATO by accepting the Agreement between the Republic of Macedonia and the Hellenic Republic?"

The impugned decision of the Assembly does not contain all the elements provided for in Article 9 of the Law on Referendum and Other Forms of Direct Expression of the Citizens ("Official Gazette of the Republic of Macedonia", no.81/2005). This Article lays down that a referendum is announced by a decision which contains: the body announcing the referendum; the territory or area where the referendum is announced; the title of the regulation, that is, issue or issues on which citizens decide in the referendum; explanation of the regulation, that is, issue or issues for which the referendum is announced; referendum question or questions, that is, one or more

\footnotetext{
6 See more details: https://www.venice.coe.int/webforms/documents/?pdf=CDL-PI(2017)007-e. 7. [...] [E]lection results may be challenged either before the Constitutional Court (for national or European elections) or the relevant administrative court (for municipal elections). Concerning the national and European elections, Article 150(1) of the Constitution confers the right to initiate proceedings before the Constitutional Court upon a few institutions. [...] CDL-AD (2011)013, Joint opinion on the election code of Bulgaria.
} 
proposals of regulations on which the citizens decide; the date of holding the referendum; and the type of the referendum.

Of these seven elements, the contested Decision does not contain four elements, that is, nos. $3,4,5$, and 7 , that is, does not contain the title of the regulation, that is, the issue or issues on which citizens decide in the referendum; there is no explanation of the regulation, that is, the issue or issues for which the referendum is announced; a referendum question or questions, that is, one or more proposals of regulations on which the citizens decide; and the type of the referendum. The referendum question was ambiguous and captious. Article 15 paragraph 4 of the Law on Referendum was not respected, that is that the question on the ballot must be precisely worded and unambiguous so that citizens in the referendum can answer with "for" or "against".

The referendum question was clear ambiguous and as such was illegal and prohibited by law. In terms of legal and substantive nature, there is no consultative referendum for entering/ leaving international organizations or associations (Separate opinion of the Constitutional Judge Cosheva). Furthermore, the Decision to announce a referendum did not specify the full name of the Agreement between the Republic of Macedonia and the Hellenic Republic, but it simply notes "the Agreement between the Republic of Macedonia and the Hellenic Republic". The Decision did not contain any explanation of the regulation, that is, the referendum question that had to be clear so that the citizens could familiarize themselves with the legal effect of the decision, that is, in no part of the Decision does it state that with the Agreement the Republic of Macedonia will change its name into the Republic of North Macedonia.

Regarding the referendum question, the Assembly adopted a decision with three intermingled (sub)questions into one to which it was impossible to give a consistent answer (FOR or AGAINST). The Law on Referendum and Other Forms of Direct Expression of the Citizens in Article 15 paragraph 3 stipulate that if it is voted on several issues, each of them should be voted for on a separate ballot. In the present case, it was not so, because the disputed Decision envisaged only one ballot on the date of the referendum. Regarding the element about the type of the referendum, the Decision states that a referendum is announced to consult the citizens and that it will be conducted on the whole territory of the Republic of Macedonia. That means that the type of referendum announced was unclear. In this case, it was particularly problematic in the beginning of the procedure whether a prior or additional referendum was announced and was the referendum mandatory or optional. The legal effect of the decision adopted in such a problematic way was quite different, and its legal effects diametrically opposite and contradictory. This incompleteness of the impugned decision brought a great deal of confusion and legal uncertainty when interpreting the results of the referendum.

The referendum held on 30 September 2018 ended without a decision by the citizens. Out of a total of 1,806,336 citizens registered in the Voters' list, only 666,743 citizens voted (i.e., 36.91

7 The Assembly should have formulated three separate questions instead of one: 1 . Are you for membership in the EU? 2. Are you for membership in NATO? and 3. Are you for accepting the Agreement between the Republic of Macedonia and the Hellenic Republic? and conducted three referendums in one day, bearing in mind that this option is given under Article 10 paragraph 2 of the Law on Referendum and Other Forms of Direct Expression of the Citizens. 
percent of the total number of registered citizens in the Voters' List). The number of unused ballots was 1,139,593. The referendum question was voted "yes" by 91.46 percent (or 609,813 citizens), while 5.65 percent (or 37,700 citizens) voted against it. As many as 19,221 ballots were invalid (2.89 percent). The decision was not adopted because the condition for a successful referendum set out in the Constitution was not met, i.e., more than half of the total number of citizens registered in the Voters' List did not vote.

This unsuccessful referendum opened the question of whether the PA would cease to be valid or would it remain in force. Also, which majority of votes will be relevant to have a legally valid decision? Is it relative of 450,000 voters, as in the case of an optional referendum, or absolute of about 900,000 voters, as in the case with a binding referendum under Article 120 of the Constitution? All this evidently represented a violation of the principle of legal certainty of the citizens.

Hence, from all these allegations it can be concluded that the Assembly has not adopted a formal decision for EU accession, as it did for NATO accession in 1993. Article 120 of the Constitution provides that only a decision proposed by at least one of the three authorized bodies, made by a qualified $2 / 3$ majority of the votes in the Assembly, may be subject to a referendum verification. According to Article 27 of the Law on Referendum, a consultative referendum may be only a preliminary referendum, i.e., for prior consultation of the citizens on issues of wider significance, which in this case was not observed because the agreement had already been signed in June 2018. The Assembly failed to use Article 24 of the Law on Referendum and Other Forms of Direct Expression of the Citizens which gives a possibility to announce a referendum "for the purpose of ratifying international agreements".

The decision of the State Election Commission (Report on the final results, 2018), which concluded that the referendum was unsuccessful was published in the Official Gazette, and it must have been mandatory for all bodies, institutions in the country, including the Government and the Members of Parliament. Nevertheless, the Macedonian authorities continued with the process of constitutional revision. The procedure was assessed as highly problematic and controversial. Article 30 paragraph 2 of the Law on Referendum states that the Assembly is obliged to regulate the issue in accordance with the results of the referendum within 60 days after the announcement of the results of the referendum. The results of the referendum held on 30 September 2018 did not authorize either the government or any other body to open the procedure of constitutional changes concerning the name and history of the country.

The fact that the institutions did not respect the will of the citizens and did not respect the sovereignty that arises and belongs to the citizens indicates a flagrant violation of the Constitution, but also the international law, according to which the legal identity of the state is inherently related to the sovereign and independent will of the citizens and this identity originally comes from the people and their right to self-determination and to determine the national and legal identity of the country as a personal and inalienable right. The right to self-determination and self-identification of every nation is related to the independent right to state self-determination when it comes to the basic elements of the state as a legal entity. The concept of the United 
Nations and the UN Charter is based on people's sovereignty, i.e. the right of the people to self-define and to self-determine in their own way.

Consequently, one could conclude the following: 1) No external regulation or act adopted outside the state can determine, create or abolish the legal identity and the name of the state; 2) No external regulation or act adopted outside the state can determine, create or abolish the national or national identity, which is subject to self-determination. By denying one's national identity, including the self-denial of one's own identity, known as auto-chauvinism, the right to existence of the people (in this case the Macedonian people) is denied too.

The right to the existence of the people and their name is an essential human right equal to the right of self-defense of the people and the state. The government has not yet explained according to which article of the Constitution it opened the procedure for changing the state's name and the national identity of the Macedonians when, as it is known, no government has a mandate or constitutional authority to change the name, collective and personal identity of Macedonians, state history, issues that have an absolute character protected by international law.

The government decided to change the Constitution and write amendments using hitherto unprecedented constitutional nomotechnics. The government approaches made changes of the phrase the "Republic of Macedonia" with the "Republic of North Macedonia", and the word "Macedonia" with the words "North Macedonia" with only one constitutional amendment, which is an unknown practice in the constitutional history and practice.

From the nomotechnical point of view, this intervention is extremely frivolous and inapplicable. Bearing the fact that in the current practice of amending the laws, and especially the Constitution, the methodology of precise statement of the facts has always been applied, i.e. what specifically is deleted, changed, or supplemented in the legal text, the newly established technique of constitutional amendments went against the established practice. Any change in the text of the Constitution must be precisely stated and contained in the constitutional amendments because only such a process can guarantee legal security.

In the Preamble, the phrase "decisions of ASNOM" is replaced by the expression "Proclamation from the First Session of ASNOM to the Macedonian people for the session of ASNOM", after the word "year" the words "and the Ohrid Framework Agreement" are added; and the words "decided to" are deleted. With Amendment XXXIV, the parliament practically deleted the decisions of ASNOM as constitutive acts of historical significance for the creation of the Macedonian state and replaced them only with the Proclamation of the First Session of ASNOM and the Ohrid Framework Agreement. The government's proposal decided to delete as many historic decisions of ASNOM, out of which four have a foundational (state-building) character for Macedonia. Thus, the government and the parliament decided to remove the following decisions:

(i) The decision of ASNOM as the supreme, legislative and executive people's representative body and the highest body of the state government of Democratic Macedonia,

(ii) ASNOM Declaration on the Basic Rights of the Citizen of Democratic Macedonia,

(iii) ASNOM's decision to introduce the Macedonian language as an official language in the Macedonian state, 
(iv) The Rulebook of ASNOM,

(v) Decision of ASNOM for establishing a Legislative Commission at the Presidium of ASNOM,

(vi) Decision of ASNOM for establishing a State Commission for determining the offenses of the occupiers and their collaborators,

(vii) Decision of ASNOM for approval of the decisions, orders and duties issued by the General Staff of the National Liberation Army and POM and the Initiative Board for convening ASNOM,

(viii) ASNOM decision for giving recognition and gratitude to the People's Liberation Army, and

(ix) Decision of ASNOM for declaring Ilinden - August 2 as a national holiday of the Macedonian state.

No one has had the mandate to remove these acts of such importance, and even less to replace them only with "the Proclamation of ASNOM". The proclamation has never had and can never have a constitutive significance. In reality, with the issued Proclamation, the Macedonian people were informed that the first session of ASNOM was held and that the foundations of the Macedonian federal state in the new, Democratic and Federal Yugoslavia, were laid. Simultaneously, the government and parliament diminished the meaning of the Second and Third Sessions of ASNOM, i.e. they are no longer mentioned or assumed in the Constitution because the amendment emphasizes the importance only of the Proclamation of the First Session of ASNOM. It is obviously an act of erasing the national history of the country and changing historical facts, based on a government's political needs. On the other hand, the fact that the Ohrid Framework Agreement was included in the Preamble is surprising, bearing in mind the 2001 constitutional amendments that had already fully implemented in practice. They have been an integral part of the Constitution for 19 years.

The Constitutional Amendment XXXV was completely pointless, given the fact that each state, through its obligation to respect international law, must respect the sovereignty, territorial integrity, and political independence of the neighboring states. AS well known, Article 8 paragraph 1 line 11 of the Constitution, states the obligation of the state to respect the generally accepted norms of the international law as a fundamental value of the constitutional order. These mandatory norms are already contained in the UN Charter, the UN Declaration on non-interference in the internal affairs of states and the protection of their independence, and sovereignty and in other acts of international character that the state is obliged to respect as a subject in international relations.

The Constitutional amendment XXXVI is also disputable, especially item 4, which refers to the care of the Republic for its citizens living abroad with the addition that this will be done without the country's interference in the sovereign rights of other countries and in the internal affairs of other countries. This is a treacherous formulation that allows, under the disguise of protection of the sovereign rights of other countries and their internal affairs, our permanent cooperation and maintaining close relations with our compatriots abroad to be hindered.

Practically with this amendment, Macedonia, instead of building bridges for cooperation and rapprochement with Macedonians around the world, built a wall with its compatriots. This amendment is completely contrary to the policy of protection of national minorities known as Kin-state 
policies, policies that are already recognized and cherished by the UN8 ${ }^{8}$ OSCE High Representative on National Minorities (Bolzano/Bozen Recommendations), good practices developed by the Venice Commission (e-Report) and by the Parliamentary Assembly of the Council of Europe.

\section{Conclusion}

The Constitutional Court did not rule on the constitutionality of the 2019 constitutional amendments, and remained silent on the 2018 referendum and the Prespa Agreement. Practically on the key issues of importance for the state, its name, history and identity, the Constitutional Court did not take any position or assessment, which is devastating for this body. Even though the Court could have come out as a strong and institutional factor that protects the Constitution, it failed to do so in any of the cases it worked on. Not once in its past work the Court managed to act as a primary factor when it comes to the interpretation of the Constitution. This task was passed to the Parliament, as a constitutional authority.

The Macedonian Constitutional Court, contrary to the European practice for constitutional justice failed to answer the key question: what does a Constitution in Macedonia mean and how the Court should act in cases that are not strictly regulated with the Constitution. It showed no interest with regard to its activism. The "activist" position in the performing of the most important authorisations (guardian of the Constitution and the laws, "watchdog" for the legislative and the executive government, protector of the human rights and freedoms) remains without a concrete effect even today. This paper explained the crucial anomalies in the work of the Constitutional Court and the missed opportunity for the Court to become leader in the systematic reforms in the Macedonian judiciary, which are still desperately needed in the judicial system in context of developing a new legal culture in the country.

\section{References}

1. Brown Keith (2003), The Past in Question-Modern Macedonia and the Uncertainties of Nation, Princeton: Princeton University Press.

2. Constitution of the Republic of Macedonia, Official Gazette of the RM, no. 52/1991. Amendment I and II from Constitution of Republic of Macedonia, Official Gazette of the RM, no. 1/1992, Amendment III from Constitution of Republic of Macedonia, Official Gazette of the RM, no. 31/1998, Amendments IV, V, VI, VII, VIII, IX, X, XI, XII, XIII, XIV, XV, XVI, XVII and XVIII from Constitution of Republic of Macedonia Official Gazette of the RM, no 91/2001,

\footnotetext{
8 "States have a responsibility to protect all people residing in their territory, be they members of majorities or minorities, indigenous peoples, citizens or non-citizens. This principle lies at the heart of the commitment to the responsibility to protect (R2P) made by all UN member states at the 2005 World Summit. R2P emerged in order to avert atrocity crimes such as genocide and ethnic cleansing-which in the past have all-too-clearly demonstrated the dangers of failing to protect people targeted by their fellow citizens or by the state. Identity-based tensions have been present in many of the conflicts that have required UN Security Council (UNSC) action since the end of the cold war, and more often than not minorities have been the principal victims". https://archive.unu.edu/publications/briefs/ policy-briefs/2010/UNU_PolicyBrief_10-02.pdf. last visit on 3th of December 2020.
} 


\section{Seccurity}

Amendment XIX from Constitution of Republic of Macedonia, Official Gazette of the RM, no. 84/2003, Amendment XX, XXI, XXII, XXIII, XXIV, XXV, XXVI, XXVII, XXVIII, XXIX и XXX from Constitution of Republic of Macedonia, Official Gazette of the RM, no. 107/2005, Amendment XXXI from Constitution of Republic of Macedonia, Official Gazette of the RM, no 3/2009, rectify an error on Amendment XXXI from the Constitution of Republic of Macedonia, Official Gazette of the RM, no. 13/2009, Amendment XXXII from the Constitution of Republic of Macedonia, Official Gazette of the RM, no. 49/2011, Amendment XXXIII, XXXIV, XXXV and XXXVI from the Constitution, Official Gazette of the RM, no. 6/2019.

3. Decision U. no. 46/1994-0-0 http://ustavensud.mk/? $p=6253$ (accessed on 20 January 2021).

4. Decision U. no. 341/1995-0-0 http://ustavensud.mk/?p=6599 (accessed on 20 January 2021).

5. Decision U. no. 140/2001-1 http://ustavensud.mk/?p=8233 (accessed on 20 January 2021).

6. Declaration on Principles of International Law concerning Friendly Relations and Cooperation among States in accordance with the Charter of the United Nations, UN General Assembly Resolution 2625 (XXV), 1970.

7. Dialogos Media (2019), "Is the Prespa Agreement Illegal? This Week, Interview with International Law Scholar Francis Boyle", 14 March, online https://dialogosmedia.org/ is-the-prespa-agreement-illegal-our-interview-with-international-law-scholar-francis-boyle/ (accessed on 6 February 2021).

8. International Covenant on Civil and Political Rights, 1966.

9. International Covenant on Social, Economic and Cultural Rights, 1966.

10. Janev Igor (1999), "Legal aspects of the use of a provisional name for Macedonia in the United Nations", The American Journal of International Law, vol. 93, no. 1.

11. Karakamisheva-Jovanovska Tanja (2017), "Macedonian Constitutional Story", Law Review, 8(1), online http://pf.ukim.edu.mk/wp-content/uploads/2019/05/9.-Prof.-Karakamisheva-Jovanovska.pdf. (accessed on 19.2.2021).

12. Karakamisheva-Jovanovska Tanja (2018), "Constitutional Justice in the Republic of Macedonia. Macedonian Constitutional Court - Legal Symphony or Legal Cacophony?", Law Review, 9(2).

13. Law for the Conclusion, Ratification, and Execution of International Agreements, Official Gazette of the Republic of Macedonia, no. 5/1998.

14. Mircev Dimitar (2001), "Engineering the Foreign Policy of a New Independent State: the Case of Macedonia", in James Pettifer (ed.), The New Macedonian Question, London: Palgrave Macmillan.

15. Nikodinovska Krstevska Ana (2019), "Prespa Agreement between the Republic of Macedonia and the Republic of Greece through the Prism of International Law", Yearbook of the Faculty of Law, No. 8, Goce Delchev University.

16. Report on the final results of the referendum voting at the state level, September 30, 2018, https://drive.google.com/file/d/1IAGxUaJI5epNrQJjM_57UHyRjR56-Aqj/view (accessed on 20 January 2021).

17. Report on the Preferential Treatment of National Minorities by their Kin-State, adopted by the Venice Commission at its 48th Plenary Meeting (Venice, 19-20 October 2001), 


\section{Silabus}

online https://www.venice.coe.int/webforms/documents/?pdf=CDL-INF(2001)019-e (accessed on 20 January 2021).

18. Rulebook of the Constitutional Court, Official Gazette of RM, no. 70/92.

19. Saveski Dejan (2020), "Procedural Unconstitutionality and Illegality of the Prespa Agreement", Zbornik pravnog fakulteta u Splitu, 57(4).

20. Separate Opinion of the Constitutional Judge, Ms. Elena Gosheva, http://ustavensud. $\mathrm{mk} / \mathrm{p}=17812$ \&lang=en. (accessed on 6 February 2021).

21. Siljanovska Davkova Gordana (2018), 'Za Prespanskiot dogovor i posiroko', [0n the Prespa Agreement and Beyond], online <http://umdiaspora.org/tag/gordana-siljanovska-davko$\mathrm{va} />$ (accessed on 6 February 2021).

22. Spirovski Igor (2009), "The Competence of the Constitutional Court to Control the Conformity of Laws with International Treaties: New Trends in Constitutional

23. Justice", Venice Commission and Constitutional Court of Montenegro, online https://www. venice.coe.int/webforms/documents/default.aspx?pdffile=CDL-JU(2009)036-e (accessed on 20 January 2021).

24. Stefov Risto, Who are the Macedonians? Their struggles to survive as a nation, e-book edition, Toronto, October, 2018, http://www.pollitecon.com/html/ebooks/Who-are-the-Macedonians.pdf (accessed on 25 January 2021).

25. The Bolzano/Bozen Recommendations on National Minorities in Inter-State Relations, las visit on 3th December, 2020. https://www.osce.org/henm/388292 (accessed on 20 January 2021). 